\title{
Oral health care for a young drug user
}

\author{
Cuidados com a saúde bucal de um jovem usuário de drogas \\ Atención de salud bucal para un joven consumidor de drogas
}

Received: 09/16/2021 | Reviewed: 09/21/2021 | Accept: 09/23/2021| Published: 09/25/2021

\author{
Lucas Lucena Camargo \\ ORCID: https://orcid.org/0000-0003-0740-860X \\ Faculdade Patos de Minas, Brazil \\ E-mail: lucaslucena2801@gmail.com \\ Gilmar Antoniassi Junior \\ ORCID: https://orcid.org/0000-0002-1809-1380 \\ Universidade de Franca, Brazil \\ Faculdade Patos de Minas, Brazil \\ Faculdade Cidade de João Pinheiro, Brazil \\ E-mail: jrantoniassi@hotmail.com
}

\begin{abstract}
Objective: to design the oral health care of a young drug user, about self-image due to the therapeutic method applied in dental care, carried out at the School Clinic of a Private College in a medium-sized city in the interior of the State of Minas Gerais, Brazil. Materials and Methods: this is an intervention research involving qualitative participant observation of the case study type, which used the interventionist method, being carried out in a Dental School Clinic of a Private Faculty. The case was intentionally selected from the assistance provided by the Triage Clinic and directed to the assistance provided by the Integrated Clinic, due to the complexity of the oral health condition resulting from drug use. The study was submitted for consideration Ethics through the CAEE: 40362620.2.0000.8078. This is a 19-year-old patient, referred to here as T, of low social class, incomplete high school, working as a barber, living with his parents in a suburb of the city. As a data collection instrumentused d the photographic record, records, diary and episodic interview. For data analysis, qualitative approach methods were used. Considerations: it can be considered positively that the evolution of the established treatment plan was positive in favor of the therapeutic intervention established as a result of the behavior presented by the patient, thus demonstrating the patient's satisfaction with the results in the context of the oral health condition, as well like, aesthetics and self-esteem.
\end{abstract}

Keywords: Oral Health; Drug addiction; Therapeutics; Health promotion.

\begin{abstract}
Resumo
Objetivo: desenhar os cuidados com a saúde bucal de um jovem usuário de drogas, acerca da autoimagem em virtude do método terapêutico aplicado no atendimento odontológico, realizado na Clínica Escola de uma Faculdade Privada em uma cidade de médio porte do interior do Estado de Minas Gerais, Brasil. Materiais e Métodos: trata-se de uma pesquisa intervenção de observação participante de natureza qualitativa do tipo estudo de caso, que fez uso do método intervencionista, sendo realizada em uma Clínica Escola de Odontologia de uma Faculdade Privada. O caso foi selecionado de modo intencional a partir do atendimento da Clínica de Triagem e o direcionamento para o atendimento da Clínica Integrada, devido à complexidade da condição de saúde bucal em decorrência do uso de drogas. O estudo foi submetido para apreciação Ética através do CAEE: 40362620.2.0000.8078. Trata-se de um paciente com idade de 19 anos aqui denominado como $\mathrm{T}$, de classe social baixa, ensino médio incompleto, exercendo atividade laboral como barbeiro, residente com os pais em um bairro periférico da cidade. Como instrumento de coleta de dados utilizou do registro de fotográfico, prontuário, diário de campo e entrevista episódica. Para as análises de dados foram utilizados métodos de abordagem qualitativa. Considerações: pode-se considerar positivamente que a evolução do plano de tratamento estabelecido transcorreu positivamente a favor da intervenção terapêutica estabelecida em decorrência do comportamento apresentado pelo paciente, demonstrando assim, a satisfação do paciente com os resultados no âmbito da condição da saúde bucal, bem como, a estética e a autoestima.
\end{abstract}

Palavras-chave: Saúde Bucal; Drogadição; Terapêutica; Promoção da Saúde.

\section{Resumen}

Objetivo: diseñar el cuidado de la salud bucal de un joven consumidor de drogas, sobre la autoimagen por el método terapéutico aplicado en la atención odontológica, realizado en la Clínica Escolar de un Colegio Privado de una ciudad mediana del interior del Estado. de Minas Gerais, Brasil. Materiales y Métodos: se trata de una investigación de intervención de observación participante cualitativa del tipo estudio de caso, que hizo uso del método intervencionista, siendo realizada en una Clínica Escuela de Odontología de una Facultad Privada. El caso fue seleccionado intencionalmente de la asistencia brindada por la Clínica de Triage y dirigido a la asistencia brindada por la Clínica 
Integrada, debido a la complejidad de la condición de salud bucal derivada del uso de drogas. El estudio fue sometido a consideración de Ética a través del CAEE: 40362620.2.0000.8078. Se trata de un paciente de 19 años, aquí referido como T, de clase social baja, bachillerato incompleto, trabajando como barbero, viviendo con sus padres en un suburbio de la ciudad. Como instrumento de recolección de datos se utilizó el registro fotográfico, la historia clínica, el diario de campo y la entrevista episódica. Para el análisis de datos se utilizaron métodos de enfoque cualitativo. Consideraciones: se puede considerar positivamente que la evolución del plan de tratamiento establecido fue positiva a favor de la intervención terapéutica establecida como consecuencia del comportamiento presentado por el paciente, demostrando así la satisfacción del paciente con los resultados en el contexto de la salud bucal. condición, así como, estética y autoestima.

Palabras clave: Salud bucal; Drogadicción; Terapia; Promoción de la salud.

\section{Introduction}

The consumption of legal and illegal drugs has increased considerably worldwide (Ferro, Gaya, \& Antoniassi Junior, 2014). According to the 3rd National Survey on Drug Use in Brazil, marijuana is the most consumed drug, followed by cocaine, where $3.2 \%$ of Brazilians have used drugs in the last 12 months, which is equivalent to 4.9 million of people. Consumption is higher in men and young people aged between 18 and 24 years; approximately 2.3 million people met criteria for alcohol dependence (Bastos, Reis, Coutinho, Souza, 2017).

However, drug use has increasingly shown a public health problem involving physical, psychological and social harm (Antoniassi Junior, Silva, Castro, \& Figueiredo, 2020; Marques et al., 2016). Given this, about oral health specifically, abusive use can generate different damages to oral health, ranging from halitosis, gingivitis and mouth cancer (Marques et al., 2016), compromising the soft tissues involved, causing tooth wear, bruxism, periodontal disease, changing the $\mathrm{pH}$ of the saliva and increasing the caries index (Maia et al., 2018).

As is known, after alcohol, marijuana is the most consumed drug in Brazil and in the world (Ferro, Gaya , \& Antoniassi Junior, 2014; Antoniassi Junior et al., 2020) when compared to the oral health status of marijuana users with nonusers, users usually have a worse oral health condition; among the main pathologies are dental caries, periodontal diseases, cannabis stomatitis, xerostomia and candidiasis; with possibilities of alterations and lesions in the epithelium of the oral mucosa and the appearance of leukoplakia and erythroblastic due to marijuana smoke (Marques et al., 2016).

Furthermore, drug users have a precarious state of oral hygiene due to different reasons ranging from loss of selfesteem, unstable lifestyle and social marginalization to which they are exposed (Antoniassi Junior et al., 2020; Maia, 2018) increasing the number of tooth loss (Maia, 2018).

Furthermore, it is important to highlight that inhalant drugs have had a harmful effect on the oral health of users; like cocaine, which is capable of eroding tooth enamel due to the user rubbing the substance on teeth and gums; not to mention crack, which is the most aggressive drug for oral health, and ecstasy, the drug that causes more damage. Crack smoke damages tooth enamel, gums, and the nerves in the mouth; on the other hand, ecstasy makes the mouth drier and evokes bruxism, damaging the entire dental arch, causing excessive daily pain (Maia, 2018; Marques et al., 2016).

Thus, it is important to emphasize that Dentistry can alleviate pain and, at the same time, contribute to psychosocial rehabilitation, as it helps, through dental treatment, the transition to multidisciplinary and multidisciplinary treatment, enabling the user to receive care integrally with regard to physical, psychological and social condition, respecting the peculiarities of the treatment (Antoniassi Junior et al., 2020; Ribeiro, Oliveira, Zambolin , Lauris , \& Tomita , 2002).

For this reason, it is necessary to have multidisciplinary interactivity in the joint treatment plan between the different professions in order to strengthen care, as, in addition to alleviating physical pain, the dentist will be supporting the redefinition of self-esteem and amplifying the possibilities of interaction social, since the user's rehabilitation implies rescuing the subject's condition of existence (Ribeiro et al., 2002). 
Consequently, the world has looked to the uncontrolled use of drugs as a policy not only to combat drug use, but to promote the well-being of all, ensuring that governments, civil society, private initiative and research institutions contribute to the transformation of the world through sustainable development through the 2030 Agenda Declaration (Brazil, 2020).

This Declaration of the 2030 Agenda for Sustainable Development establishes principles and commitments that are contained in an ambitious and transforming vision of the world, providing for the freedom of the population from problems such as poverty, misery, hunger, disease, violence, inequalities, unemployment, environmental degradation, exhaustion of natural resources and many others; through actions defined in 17 goals and 169 global goals to be achieved by the year 2030 (Brazil, 2020; United Nations [UN], 2015).

Thus, object 3 of Agenda 2030 ensures a healthy life and promotes well-being for all, at all ages, more specifically target 3.5, which establishes the need to strengthen the prevention and treatment of abuse of substances, including the abuse of narcotic drugs and the harmful use of alcohol (UN, 2015).

It is in this prospect proposed in goal 3 and goal 3.5 of Agenda 2030 that this study had as its guiding question: how can the therapeutic method applied in dental care contribute to the self-image and social reintegration of drug users? It is believed that due to damage to health in its entirety - physical, mental and social, it is perceived that damage to oral health affects the person's self-image and their social interaction. However, when receiving interventional care, these will enable a new possibility of social existence, promoted by the relief of pathological discomfort caused by drug use.

This research aimed to design the oral health care of a young drug user, about self-image due to the therapeutic method applied in dental care, carried out at the School Clinic of a Private College in a medium-sized city in the interior of the State of Minas Gerais, Brazil.

\section{Methodology}

\subsection{Nature of Study}

This is a qualitative participant observation intervention research of the case study type, which used the clinical intervention method to produce a description and reflection on the oral health care of a drug user associated with self-image, in the perspective promoting health and social representation in relation to OSD goal 3 target 3.5 to strengthen the prevention and treatment of substance abuse, including the abuse of narcotic drugs and the harmful use of alcohol (UN, 2015).

However, there is currently an action to favor the desire for alternatives in the model of "doing" research, which are also adapted to the practices of different groups (Dias \& Gama, 2014) inserted in different contexts of cities and different classes. Hence the need for an investigation that approaches the reality experienced by the researcher with the subject participating in the study in relation to the therapeutic method used.

\subsubsection{Participating Observer Researcher}

Within the so-called qualitative methodologies, we have a technique called Participant Observer. It is characterized by the investigator's direct contact, where he becomes the research instrument, inserting himself within the group being investigated (Mônico, Alferes, Parreira, \& Castro et al., 2017).

The fact that the observer enters the environment and actively participates in habits of another culture, makes it necessary to be able to adapt to different situations. Therefore, it is a method that requires disciplined training, preparation, knowledge, in addition to attributes such as sensitivity, attention and patience (Mônico et al., 2017).

The researcher who joins the group must make clear their role as an observer, but also as a participant in the process. Thus, it will provide favorable conditions to observe all actions, which, in the presence of strangers, might not occur (Whyte , 
2007).

\subsubsection{Intervention Research}

Intervention research makes the researcher assume in their field of investigation and research a direct relationship with the subject being investigated in relation to the phenomenon studied, directly verifying the effects that the intervention has on the participant, enabling the data analysis to be aggrandized by the direct results of what was investigated and carried out (Mendes, Pezzato, \& Sacardo, 2016).

Given this, intervention research is part of the nature of the qualitative study method, where the results achieved in relation to the technique used are verified through the direct intervention of the researcher with the participant in the study (Antoniassi Junior, 2019).

\subsection{Location d and Study}

The study was carried out in a Dental School Clinic of a Private Faculty located in a medium-sized city in the interior of the State of Minas Gerais, Brazil, in the Alto Paranaiba region. According to data from the Brazilian Institute of Geography and Statistics (Brazil, 2019), in 2018 this city had an estimated population of 150,893 inhabitants. Specifically, in the last census of 2010 the population corresponds to 138,710 inhabitants, with 51\% women and 49\% men. The Faculty has 26 higher education courses, including the Dentistry course authorized by the Ministry of Education (MEC) in the first semester of 2006 and recognized in 2012 through Ministerial Ordinance No. 317 of 12/27/2012. The Clinic School of Ontology is structured in POLICLÍNICA where internships in Biomedicine, Physiotherapy, Dentistry, Pharmacy and Nursing work (Coimbra, 2020).

\subsection{Procedures $d$ and Collection $d$ and data and Participant $d$ Research}

\subsubsection{Selection Criteria}

The case was intentionally selected from the Triage Clinic service and the referral to the Integrated Clinic service, due to the complexity of the oral health condition presented by the patient after the clinical examination. However, the inclusion criterion was the complexity of the case, having used drugs, the patient being over 18 years of age and willing to authorize the observation of the medical record and the conduction of the discharge phase of treatment in the course of the intervention in the dental school clinic. As an exclusion criterion, the patient's negative condition was established. Therefore, the Informed Consent Form (FICF) was immediately presented at the first consultation with the return of the patient's discharge phase care that occurred in the 1 st semester of 2021.

\subsubsection{The Case}

This is a 19-year-old patient, referred to here as T, of low social class, incomplete high school, working as a barber, living with his parents in a suburb of the city.

$\mathrm{T}$ presented as the main complaint pain in elements 11,12,13, 21 and 35, questioning dissatisfaction with the aesthetic appearance of the smile. During the anamnesis, it was possible to observe that the patient used drugs throughout his life, not reporting the specific time of use, but saying that he has not used drugs for a year.

Regarding oral health care, $\mathrm{T}$ said that his last dental appointment was 4 years ago (around 2015) and stating that appointments are not frequent; does not floss frequently and brushes teeth only once a day; has gingivitis and a bad taste in the mouth; saying they have mouth breathing habits; halitosis and tartar. In figure 1 it is possible to observe the state of the 
patient's oral cavity.

Figure 1. State of the oral cavity of the patient in the clinical examination

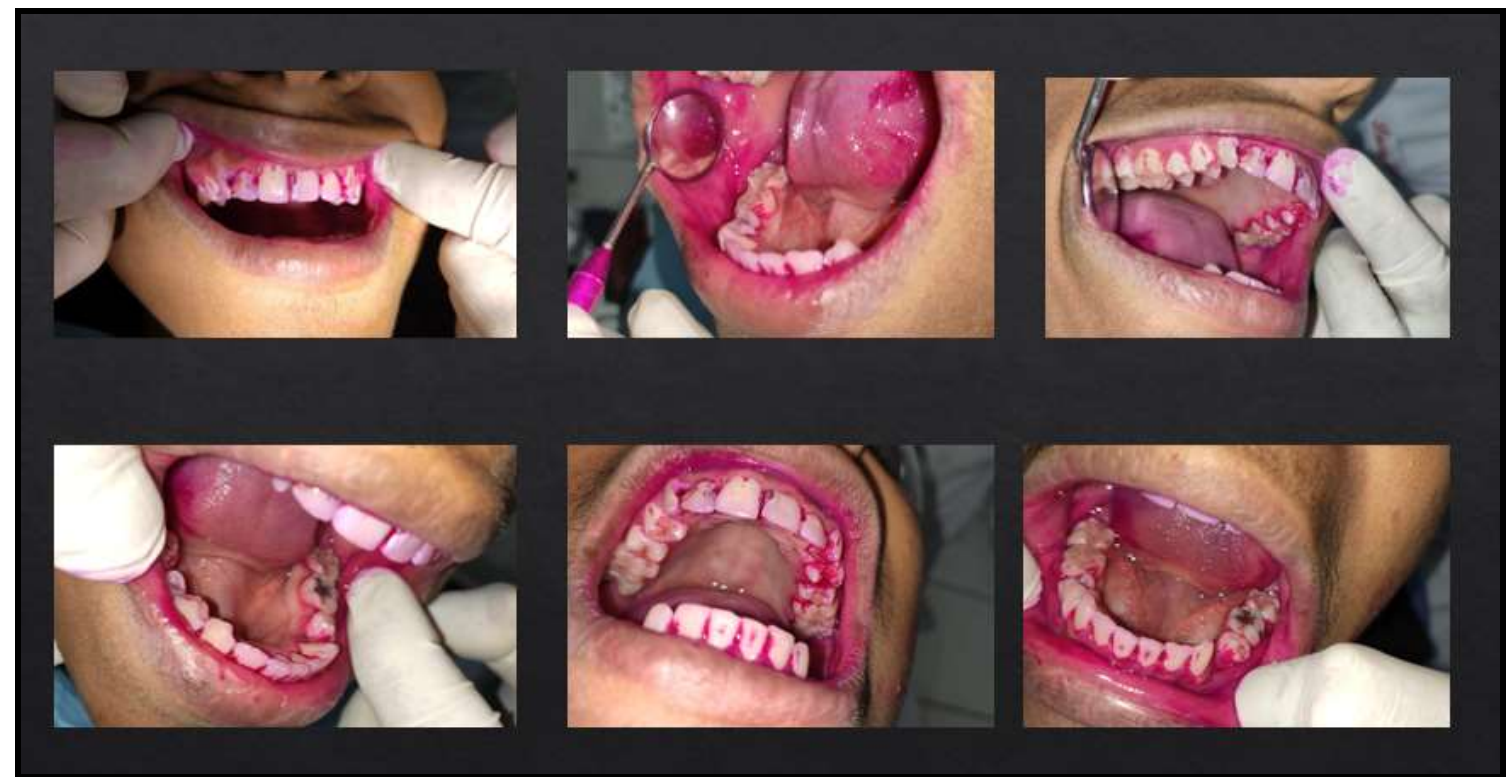

Source: Research data.

As for the clinical examination, table 1 presents the results; in the periodontal examination, no periodontal pocket was identified through the program that was performed, as can be seen in table 1; the figure 2 shows the lesions identified by radiographic examination.

T reported having undergone eye surgery due to a knife in the eye region and indicated that he had no other medical pathology or imperfections that would make it impossible to perform any type of interventional treatment. 
Table 1. Results of the patient's clinical examination

\section{Upper Arcade Elements}

18 - Absent

17 - Restoration of resin " od ," p unsatisfactory - class ii

16 - Restoration of unsatisfactory "o" resin - class i

15 - Restoration of unsatisfactory "o" resin - class i

14 - Restoration of unsatisfactory "o" resin - class $\mathrm{i}$

13 - Caries lesion "m, p" - class iii

12 - Restoration of unsatisfactory resin "d", extensive caries lesion in the mesial - class iii

11 - Restoration of unsatisfactory resin "m", caries lesion "d" - class iii

21 - Restoration of unsatisfactory resin " $m$ " with infiltration and caries lesion - class I

22 - Health

23 - Caries lesion "m" - class i

24 - Restoration of unsatisfactory resin " mo ", caries lesion "d" - class ii

25 - Restoration of unsatisfactory resin "o" - class ii

26 - Restoration of unsatisfactory "o, p" resin - class i

27 - Restoration of unsatisfactory " mo " resin - class $i$

28 - Absent

\section{Lower Arcade Elements}

38 - Absent

37 - Restoration of unsatisfactory "o" resin - class i

36 - Unsatisfactory "o" amalgam restoration - class $\mathrm{i}$

35 - Restoration of unsatisfactory "o" resin - class i

34 - Absent

33 - Health

32 - Health

31 - Health

41 - Health

42 - Health

43 - Health

44 - Restoration of unsatisfactory "o" resin - class i

45 - Caries lesion in the "o"

46 - Unsatisfactory "o" amalgam restoration - class i

47 - Restoration of unsatisfactory "o" resin - class i

$48-$ Absent

Source: Research data. 
Research, Society and Development, v. 10, n. 12, e425101220713, 2021

(CC BY 4.0) | ISSN 2525-3409 | DOI: http://dx.doi.org/10.33448/rsd-v10i12.20713

Figure 2. Results of radiographic examination of the patient.

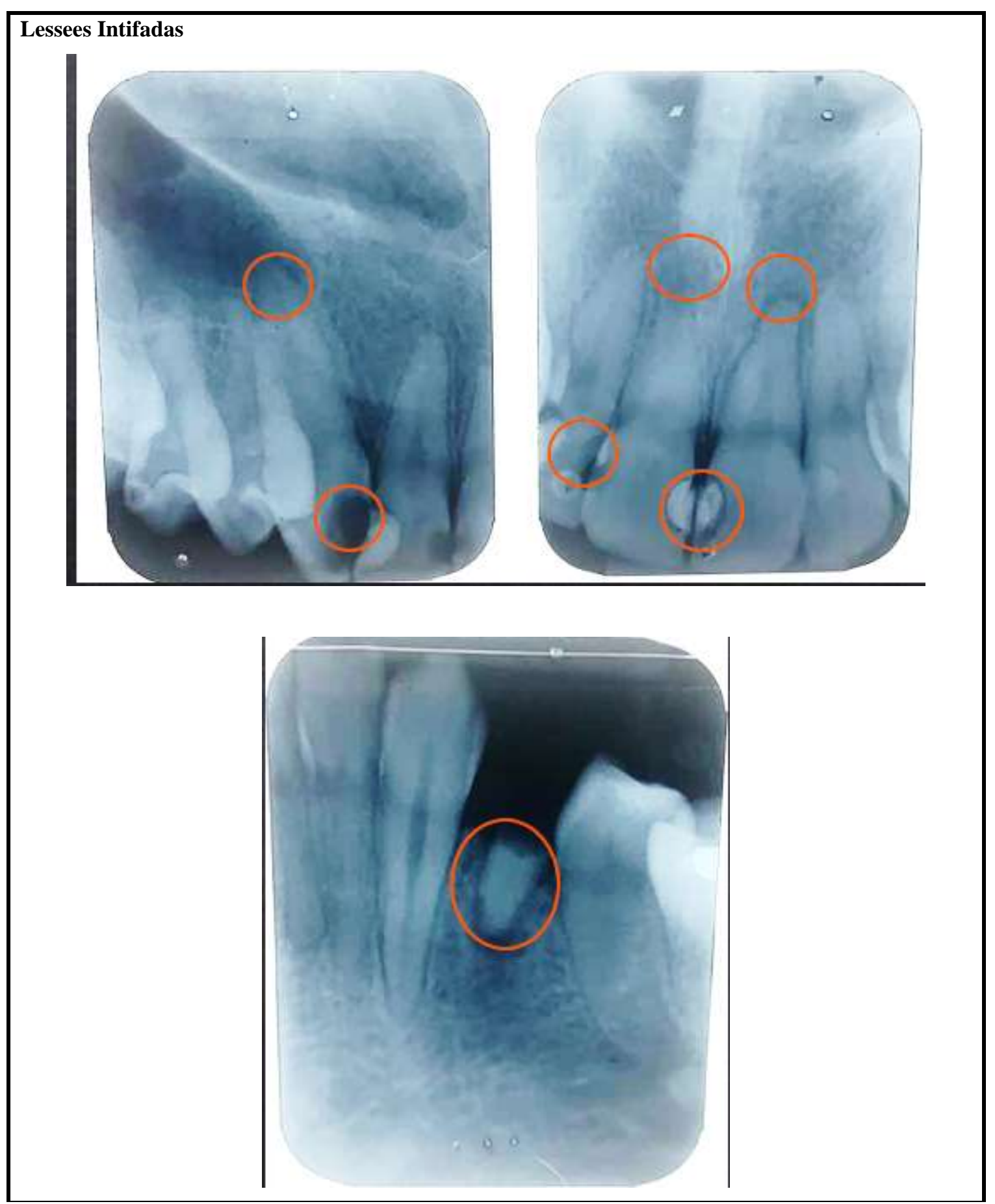

Source: Research data.

In figure 3 it is possible to verify the scan of the patient's periodontal exam. 
Research, Society and Development, v. 10, n. 12, e425101220713, 2021

(CC BY 4.0) | ISSN 2525-3409 | DOI: http://dx.doi.org/10.33448/rsd-v10i12.20713

Figure 3. Scanning of the patient's periodontal examination.

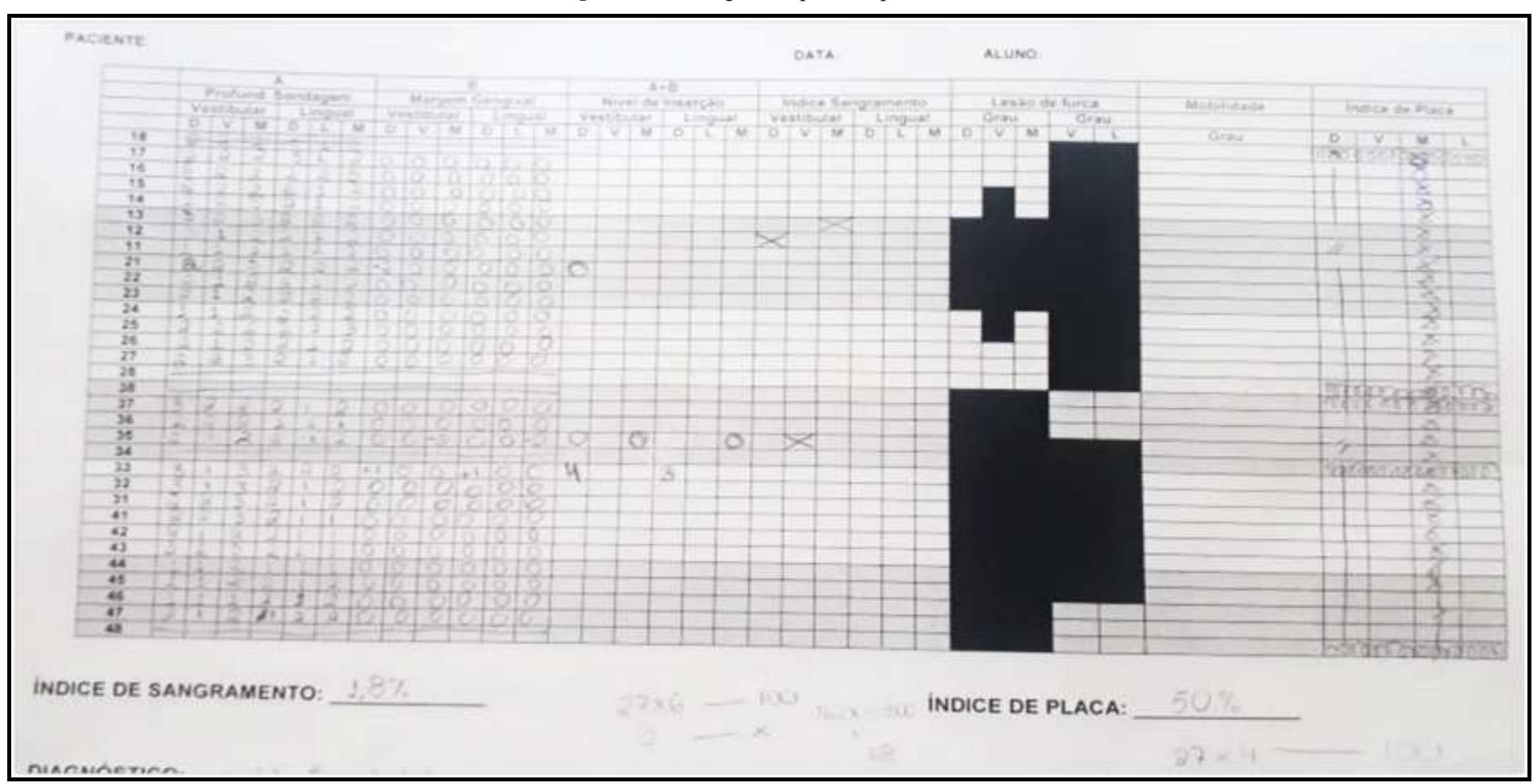

Source: Research data 
As for the patient's treatment plan, the following dental therapeutic method of intervention was established:

1. Provide guidance for supervised oral hygiene;

2. Carry out initial and final prophylaxis;

3. Extraction of the residual tooth root 34;

4. Carry out vitality test on teeth $11,12,13$ and 21 and in case of negativity proceed to endodontic procedure;

5. Perform finishing and polishing restorations in order to check for infiltration and need for replacement; and

6. Perform necessary restorations as per the procedures.

\subsubsection{The Research Instrument}

As a data collection instrument, photographic records, medical records, field diaries and episodic interviews were used to obtain the necessary information.

Photographic Record: consisted of monitoring the performance of the work, that is, to assess the evolution of the treatment in relation to the therapeutic method used in the intervention. According to Vergara (2006), it is necessary for the researcher to adopt a posture of immersion in what is being investigated in order to question the researched person about everything that is around them, what was recorded in the photo and what it represents about their reality. Given this, the point of investigation consisted of the following question to the participant: 1) what does this image remind you of? 2) what do you see in this image?

Recording of Medical Records: consisted of observing the evolution and conduct of the procedures performed in relation to the dental therapeutic method used. For this purpose, only records such as: 1) patient data; 2) initial complaint; 3) definition of the treatment plan and 4) techniques and procedures used in the case.

Field Diary: consisted of writing down all the observations relevant to the case in relation to the study investigation and in relation to the therapeutic method used in conducting the intervention with the patient. In this logic, Freitas and Pereira (2018) state that the field diary allows recording experiences in order to facilitate reflection and review of their practical conduct, being a resource that allows systematizing experiences to later analyze the results. Given this, a daily record was made of the appointments that occurred during the patient's discharge phase.

Episodic Interview: consists of a research model of the central element being the periodic invitation to the presentation of narratives of situations. The starting point for an episodic interview is the assumption that the experiences that the person acquires in a given domain are stored and remembered in the form of narrative-episodic and semantic knowledge (Bauer \& Gaskell, 2018). Given this, a dialogue was opened with the patient in the last visit, inquiring about the experience lived in the rehabilitation care of the oral health condition and how he was feeling.

\subsubsection{Data Collection Procedures}

Data collection was carried out by one of the researchers who are members of the Research Group on Culture, Subjectivity and Psychosocial Promotion of the Center for Studies and Research in Applied and Clinical Psychology School (CEPPACE) linked to the Department of Graduate and Postgraduate Studies in Psychology (DPGPSI) of the Patos de Minas College.

Considering that the therapeutic procedure started on August 13, 2019 at the Triage Clinic internship, soon followed by the care procedures, it was understood that the case was ongoing at the Dental School Clinic in accordance with the treatment plan established with to the research participant.

Given this, with the possibility of a case study, the researcher presented the research proposal to the participant, 
explaining the objectives and purpose of the study proposed here. Soon after, the Informed Consent Term (TCLE) was read, seeking to clarify all the doubts required, and it was signed by those involved.

Thus, following the proposal established in this study in the conclusion phase for the participant's discharge, soon the completion of the dental procedures was carried out in the last consultation, the episodic interview which the participant concerned about his experience during treatment in relation to the before and after.

Regarding the handling of the photographic recording technique, the researcher directed the participant in front of the computer screen, therefore, he gave the orientation exposing: at this moment I would like you to refer (return) to the beginning of your treatment, I will show some images and I would like you to tell me - what does this image remind you of? What do you see in this image? Firstly, images were shown from the beginning to the end of the treatment and in each image the question (what does this image remind you of? What do you see in this image?) was repeated.

Therefore, a free dialogue was established about the therapeutic method performed to capture information about the patient towards the treatment in relation to: their self-image and how they have been feeling, seeking to identify how the therapeutic action has remedied the damage to their oral health has and/or may have changed something in your life with regard to social relationships - interpersonal in society .

\subsection{Analysis d Data}

Methods of qualitative approach were used for the analysis, taking as a reference the Social Representations proposed by Serge Moscovici (2015) and the concept of Health Promotion and Oral Health. According to Minayo (2014), qualitative analysis is the process carried out from the transcripts of the collected material. It is necessary to gather the material and carry out a pre-analysis, guided by the construction of initial assumptions that served as support for interpreting the results.

Therefore, it was necessary to perform a floating reading of the data, respecting some qualitative validity criteria, such as exhaustiveness-representativeness-homogeneity (Minayo, 2013) in the construction of the coding, it was necessary to capture more significant words, speeches and expressions that appeared with greater regularity in pre- analyzed materials. Regarding the interview data, after transcribing the reports and observations from the field diary, thematic categorization was followed, taking into account the use of Conversation and Speech Analysis (Bauer \& Gaskell, 2015; Gomes, 2014; Myers, 2015).

\subsection{Ethical Aspects of the Research}

The present research complied with the ethical principles according to the CNS Resolutions $n^{\circ}$. 466/2012 and number $510 / 2016$ for research with human beings. For that, the research was submitted, through the necessary documentation for ethical analysis and follow-up by the Research Ethics Committee of Faculdade Patos de Minas, through CAEE: 40362620.2.0000.8078 with the approval of the research.

Benefits of the Research: from the reflection and understanding about the relationships in different scenarios to promote oral health care and quality of life, enabling the production of reflections that encompass social, human, health and self-perception issues regarding their physical condition, social and emotional in order to bring about changes in lifestyles and new possibilities.

Research Risks: in relation to risks, it is necessary to understand that these involve different scenarios regarding the researcher and the participant due to the interventionist research method. Regarding the care of the participant, when he was seen at the school clinic for the application of the therapeutic method, it is worth emphasizing the need to protect the participant with protective glasses and bib in order to minimize the risk of transmission of infections in dental practice, given 
the risk of splashing secretions directly into the eyes or contact with aerosols. Regarding the care taken by the researcher, he was supported by individual protection equipment such as: gloves, masks, cap, lab coat and glasses; so that he was also protected from infectious risks, it being important to be careful with the cleaning of instruments and the care space.

As for conducting the final interview to probe the social representation about self-image and treatment results regarding the application of the therapeutic method, it could generate anxiety and tension in the patient about the reflections produced; for that, it was emphasized that if it was in the interest of the same to establish a deeper and psychotherapeutic dialogue, a psychological reception was provided by one of the members of the Research Group 'Culture, Subjectivity and Psychosocial Promotion' of CEPPACE-DPGPSI-FPM and later forwarded to the Psychology Service of Faculdade Patos de Minas at Clinical School.

Social Relevance of the Research: as this is an interventionist research regarding the conduct of a case treated at the Clinic School of Dentistry as a result of damage to the oral health of the drug user, the study was relevant in the reflections produced on the restoration of the dignity of the patient when lost due to damage to self-image and mouth due to drug abuse. It was in this sense that the research became relevant, as it made it possible to discuss ways to intervene with these patients seen as special in the dental office.

\section{Results and Discussion Post-Treatment}

Table 2 shows the result of the patient's clinical examination at the end of dental treatment; and figure 4 shows the result of the post-treatment radiographic examination.

Table 2. Results of the clinical examination of the patient, post-treatment.

\begin{tabular}{|ll|}
\hline Upper Arcade Elements & Lower Arcade Elements \\
18 - Absent & $38-$ Eruption process \\
17 - Satisfactory Class II restoration & $37-$ Satisfactory Class I restoration \\
16 - Satisfactory occlusal restoration & $36-$ Satisfactory Class I restoration \\
15 - Class I restoration & $35-$ Satisfactory Class I restoration \\
14 - Satisfactory Class I restoration & $34-$ Absent \\
13 - Satisfactory Class III restoration & $33-$ Healthy \\
12 - Satisfactory Class III restoration & $32-$ Healthy \\
11 - Satisfactory Class III restoration & $31-$ Healthy \\
21 - Satisfactory Class III restoration & $41-$ Healthy \\
22 - Healthy & $42-$ Healthy \\
23 - Satisfactory Class I restoration & $43-$ Healthy \\
$24-$ Satisfactory Class II restoration & $44-$ Satisfactory Class I restoration \\
25 - Satisfactory Class I restoration & $45-$ Satisfactory Class I restoration \\
26 - Satisfactory Class I restoration & 46 - Satisfactory Class I restoration \\
27 - Satisfactory Class I restoration & $47-$ Satisfactory Class I restoration \\
$28-$ Absent & $48-$ Eruption process \\
\hline
\end{tabular}

Source: Research data.

Figure 4. Results of the radiographic examination of the patient, post-treatment. 
Research, Society and Development, v. 10, n. 12, e425101220713, 2021

(CC BY 4.0) | ISSN 2525-3409 | DOI: http://dx.doi.org/10.33448/rsd-v10i12.20713

Figure 4. Results of the radiographic examination of the patient, post-treatment.

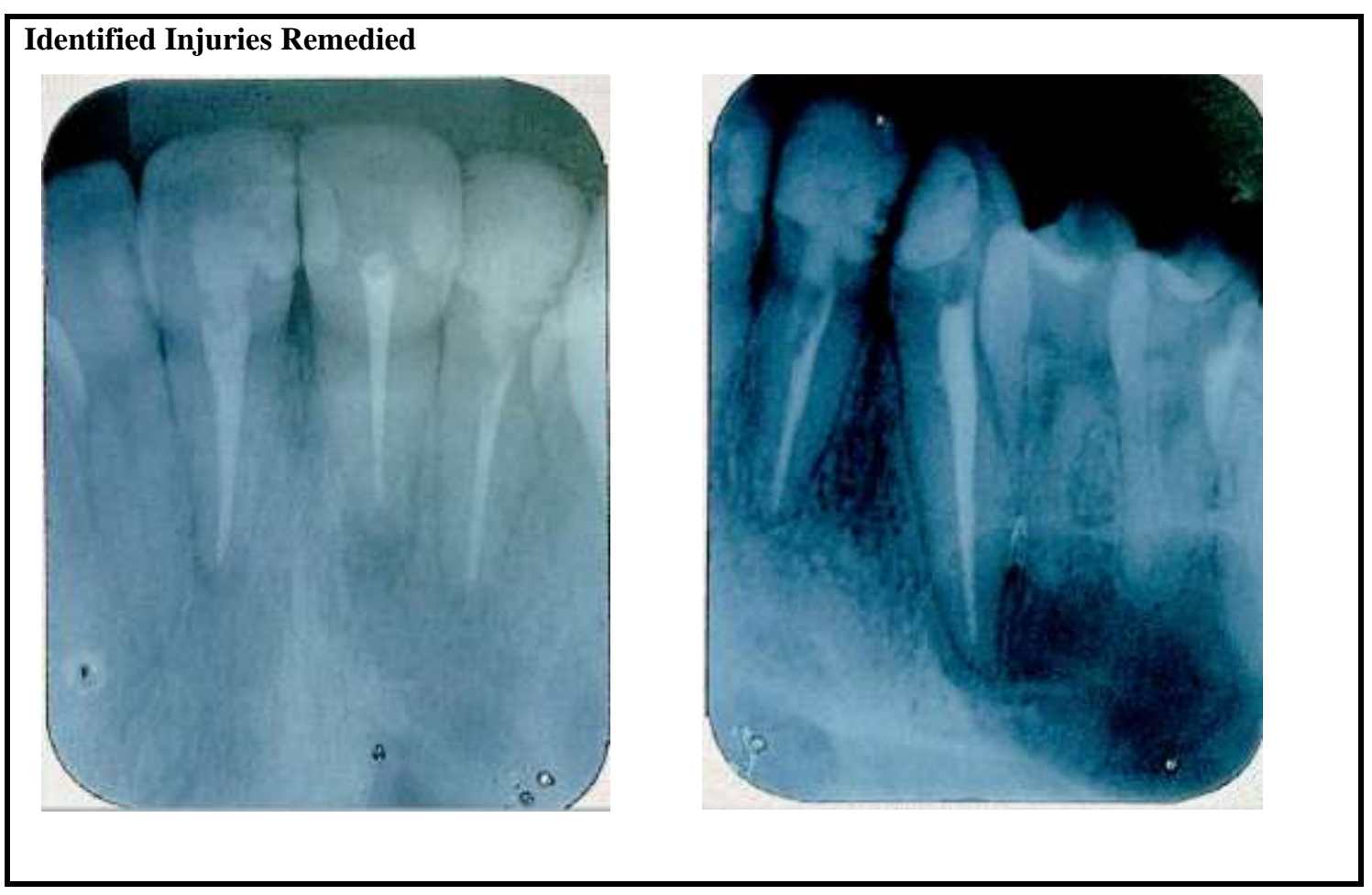

Source: Research data.

Since the figures 5 and 6 show the condition of the oral cavity of the patient in the clinical examination, at the end of the dental and periodontal examination scanning the patient, after treatment, respectively.

Figure 5. Status of the patient's oral cavity on clinical examination, after treatment.

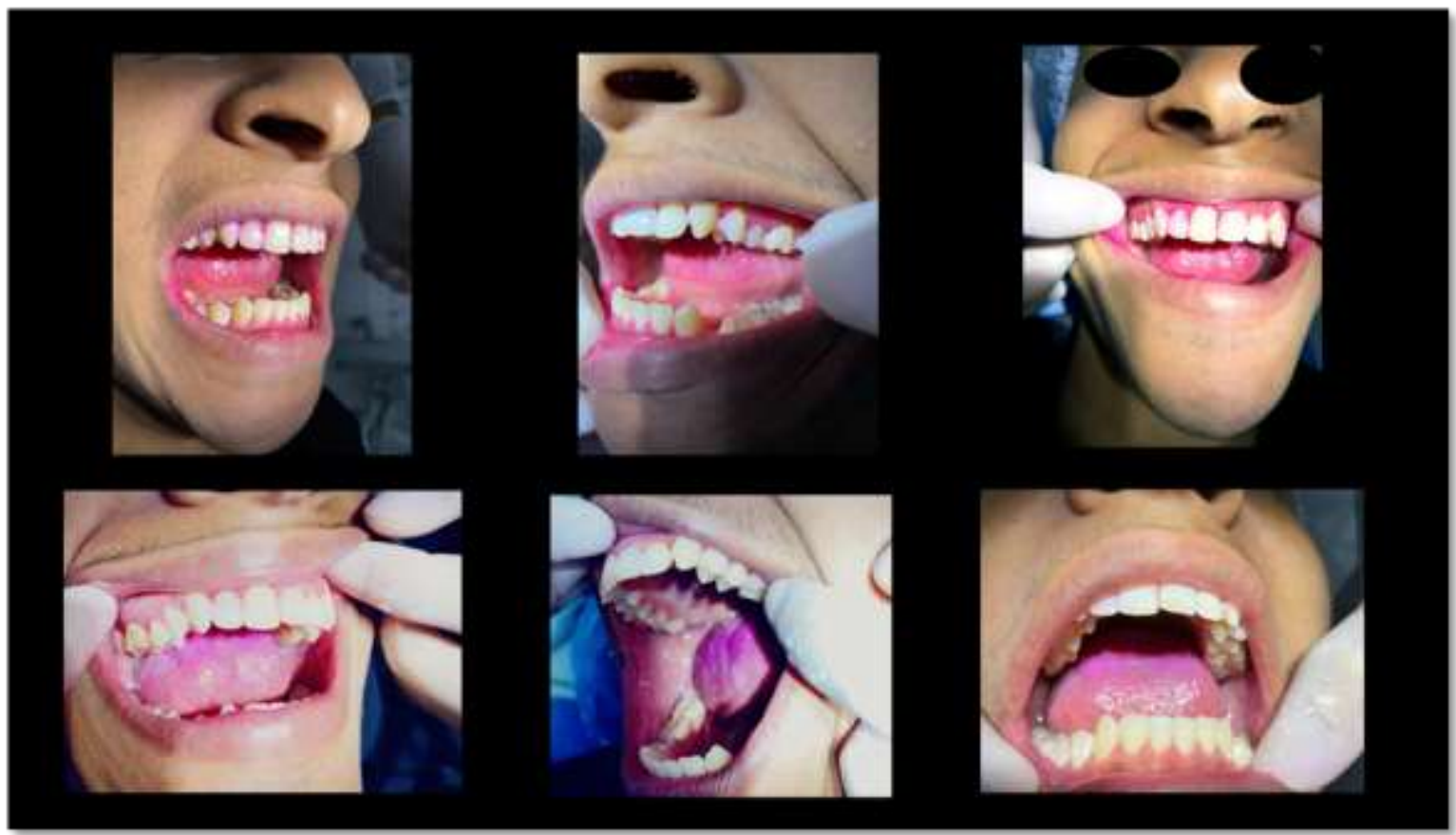

Source: Research data. 
Research, Society and Development, v. 10, n. 12, e425101220713, 2021

(CC BY 4.0) | ISSN 2525-3409 | DOI: http://dx.doi.org/10.33448/rsd-v10i12.20713

Figure 6. Post-treatment scan of the patient's periodontal examination.

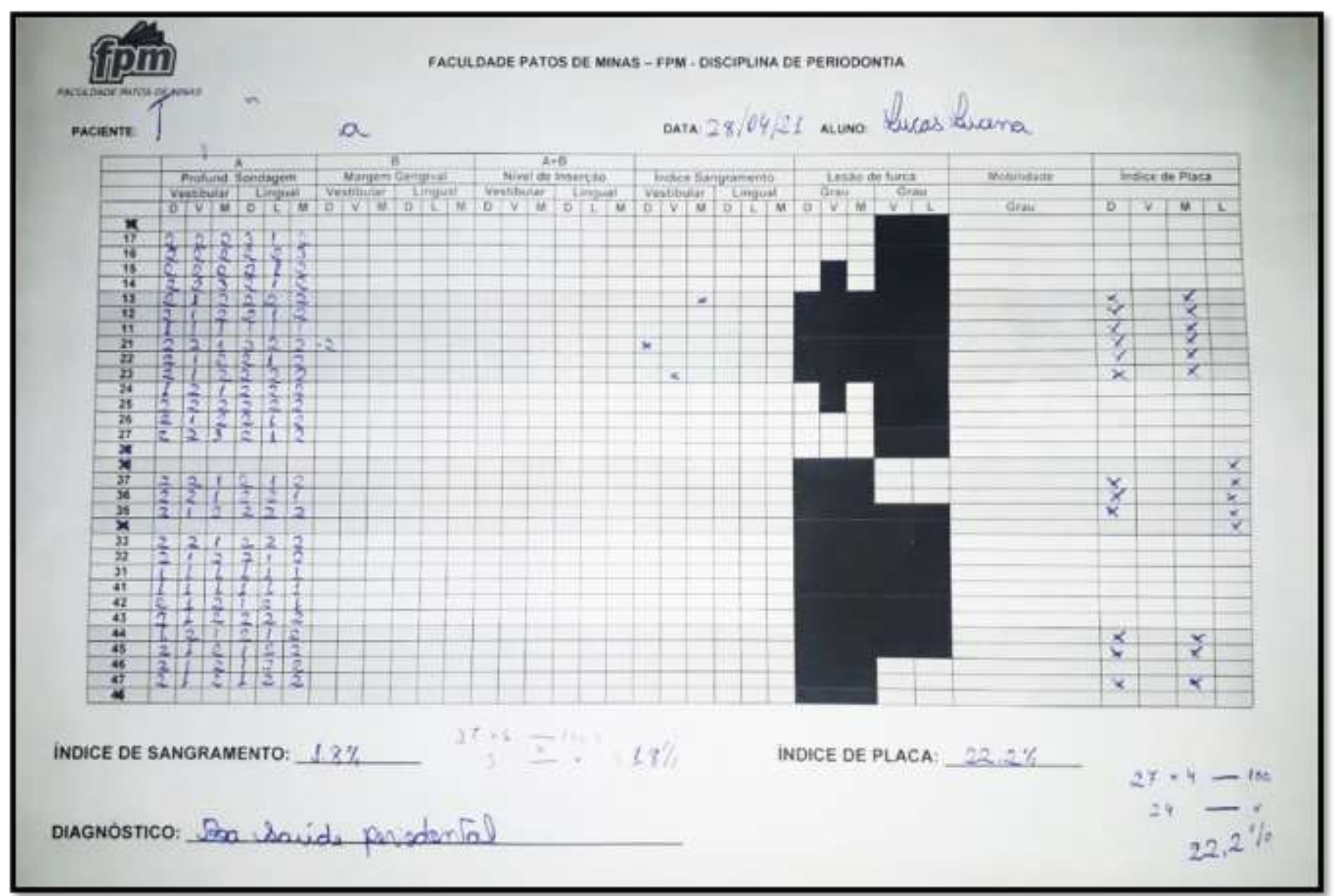

Source: Research data. 
Regarding the patient's treatment plan established as a dental therapeutic method of intervention, anamnesis, radiographic examinations and vitality tests were analyzed in some dental elements. The need for endodontic treatment and replacement of some unsatisfactory restorations was concluded, starting the dental treatment. After the replacement of unsatisfactory restorations, the endodontic treatment of elements 11, 12, 13 and 21 was started, as well as the practice of guidance for supervised oral hygiene.

Oral health care must be intensified, due to a weakness and a lack of knowledge of how important the routine practice of hygiene is, lacking a little more in-depth knowledge about the damage caused by the lack of action (Ferreira, Teixeira, Gonçalves, \& Cristo, 2020).

As for the procedure for performing the vitality test on teeth 11,12, 13 and 21, it was proven that the indicated elements were all necrotic. Therefore, the proper approach in this case was the endodontic treatment so that there was a regression of the endodontic lesion, and the expected result was duly achieved.

The principle of endodontics is to eliminate as much as possible of microorganisms and bacteria from the root canal, also using materials that are minimally aggressive to the periapical tissue, contributing to the success of the treatment (Pinheiro, Rosa, Silva, Lima, \& Anjos Neto, 2019).

As for the verification of the restorations, the need to exchange 6 occlusal restorations was identified. Restorations treatment was also carried out, spending an average of 4 sessions for each tooth, with approximately 100 procedures being performed; at the end of the execution, it can identify the reestablishment of the masticatory and aesthetic function, also leading to pain relief.

The condition of oral aesthetics is related to the individual's social health condition; study conducted with 150 patients from the Dental School Clinic of the Federal University of Campina Grande (UFCG), located in the city of Patos, located in the State of Paraiba (PB), aged over 18 years, of both genders, on the psychosocial impact of dental esthetics, reveals that dental esthetics had a great psychosocial impact on the patients' routine and as a result self-esteem was low according to the results obtained in the research (Vieira, 2021).

During the treatment, awareness work was carried out on the routine use of tobacco, reaching the end of the treatment, the patient indicated that he had stopped using it. Thus, it was demonstrated that the reflective work with regard to sensitization with the patient as a result of smoking is an important public health problem in Brazil and in the world through the selfperception of risk for various chronic diseases, including oral diseases, such as mouth cancer and periodontal disease, contributing to the cessation of this habit with a positive effect on oral health (Antoniassi Junior, Santana, \& Silva, 2016).

Regarding the perception of self-image, the patient indicated that he was satisfied with the result of the treatment, providing the rescue of self-esteem and facilitating social interaction through the restoration of the patient's positive oral health status.

My smile was detonated, needing to take care... I felt a lot of pain in chewing... a full-on smile. Taking care here at the Dental Clinic was good... it was what I expected, I would do it all over again if I needed to. Today I look at my image and see that it has improved... I can smile without being ashamed of my smile (Patient).

The data revealed in relation to the level of patient satisfaction with the care provided at the Clinical School are similar to the results of a survey carried out with 200 adult patients in relation to the dental care offered by the Dentistry Clinic of Faculdade Leão Sampaio, where most users participating in the research showed great satisfaction with the quality of the dental service provided (Sousa, Souza, \& Araújo, 2015). 
Therefore, considering the data from the initial evaluation of the case and after treatment, it was possible to observe a significant improvement from the beginning of the treatment to the end of it, with an improvement not only in the masticatory function, but also in self-esteem.

\section{Conclusion}

As this is a case involving damage to oral health as a result of drug use, it can be considered positively that the evolution of the established treatment plan was positively in favor of the established therapeutic intervention.

One of the positive aspects of conducting the treatment was the fact that the patient established assertive behaviors such as attendance to scheduled procedures, availability of dialogue for educational interventions, replication of hygienic care and always being on standby. Another significant aspect was the patient abandoning the use of drugs, which favored the restoration of the oral health condition, contributing to achieving the expected result.

However, upon reaching the conclusion of the treatment after 18 months, it was possible to evidence the patient's satisfaction with the results in the context of the oral health condition, as well as aesthetics and self-esteem, giving him the opportunity to recognize and live by relocating socially. However, this study makes it possible, as a future study suggestion, to explore the social consequences that impact on people's lives when the oral health condition in social life is reestablished.

\section{Acknowledgments}

To the Culture, Subjectivity and Psychosocial Promotion Research Group and the Clinical School of Dentistry at Faculdade Patos de Minas.

\section{References}

Antoniassi Junior, G. (2019). Different research methods in qualitative analysis to promote health. Journal of Psychology and Health in Debate, 5, 107-110, suppl. 1.

Antoniassi Junior, G., Santanta, M L, \& Silva, T H S (2016). The Exhibition of Tobacco Use and the University's Health Condition. Brazilian Journal of Forensic Sciences, Medical Law and Bioethics, 5(2), 183-197.

Antoniassi Junior, G., Silva, E J R, Castro, G G C, \& Figueiredo, G L A (2020). Profile and consumption or users and psychoactive drug substances and treatment. International Journal of Development Research, 10(1), 33520-33524.

Bastos, F I M V, Reis, R B, Coutinho, N B, \& Souza, C F (org.) (2017) III National Survey on the use of drugs by the Brazilian population. Rio de Janeiro: FIOCRUZ/ICICT.

Bauer, M W, \& Gaskell, G. (2015) Search qualitative with text, image and sound (13th ed.). Petropolis: Voices.

Bauer, M W, \& Gaskell, G. (2018). Qualitative Research with Text, Image and Sound: a practical annual. (13th ed.) Petrópolis: Editora Vozes.

Brazil. (2020). Brazilian Indicators for Sustainable Development Goals. Retrieved on November 19, 2020, from https:odsbrasil.gov.br/home.

Brazil. Brazilian Institute of Geography and Statistics (2019). Census Municipal Indicators. Retrieved on November 15, 2020, from https://cidades.ibge.gov.br/brasil/mg/patos-de-minas/pesquisa/23/25124.

Coimbra, F G (2020). Institutional Development Plan (PDI) 2016-2020. Retrieved on: November 19, 2020, http://www.faculdadepatosdeminas.edu.br/pdf/pdi.pdf.

Dias, S., \& Gama, A. (2014) Community-based participatory research in public health: potentials and challenges. Revista Panamericana de Salud Pública, 35(2), 150-154.

Ferreira, A C, Teixeira, K F, Gonçalves, I A A, \& Cristo, M I G (2020). Hygiene b ucal in old age: a case study of the knowledge of the measures of prevention. Proceedings of the UNIFACIG Congress of Geriatrics and Gerontology,1(1).

Ferro, L R M, Gaya, C M, \& Antoniassi Junior, G. (2014) Violence and drug use among university students. Brazilian Journal of Forensic Sciences, Medical Law and Bioethics, 3(3), 258-272.

Freitas, M., \& Pereira, E R (2018). The field diary and its possibilities. Quaderns of Psychology, 20(3),235-244.

Gomes, R. (2014). Search qualitative in health. São Paulo: Syrian-Lebanese Institute of Teaching and Research. 
Research, Society and Development, v. 10, n. 12, e425101220713, 2021

(CC BY 4.0) | ISSN 2525-3409 | DOI: http://dx.doi.org/10.33448/rsd-v10i12.20713

Maia, I S, Pacheco, I M, Monteiro, J V V, Casagrande, J C C, Almeida, F X, Borges, K F L et al. (2018). Oral alterations present in drug users. Revista Esfera academic health, 3(1), 10-17.

Marques, L A R V, Lotif, M A L, Rodrigues Neto, E M R, Nunes Neto, A., P., Melo, C C S A, \& Lobo, P L D (2016). Drug abuse and its consequences on oral health: a literature review. Journal of the Faculty of Dentistry of Lins/ Unimep , 26(1), 29-35.

Mendes, R.; Pezzato , L M, \& Sacardo , D P (2016). Intervention research in health promotion: methodological challenges of researching “with”. Ciência \& Saúde Coletiva, 21(6), 1737-1746.

Minayo, M C S (2013). The challenge of social research. In: Minayo, $\quad$ M C S, Deslandes, S F, \& Gomes, R. Social Research: Theory, Method, and Creativity, 9-29.

Minayo , M C S (2014). The challenge of knowledge: research qualitative in health, 406

Mônico, L., Alferes, V., Parreira, P., \& Castro, P A (2017). Participant Observation as a qualitative research methodology. Proceedings - Qualitative Research in Social Sciences, 3, 724-733.

Moscovici, S. (2015). Social Representations: research in social psychology. (11a and d.). Petropolis: Voices.

Myers, G. Analysis of conversation and speech. In: Bauer, MW, \& Gaskell, G. (Orgs). (2015) Search qualitative with text, image and sound: a manual handy. (13th ed). Petropolis: Voices, 271-292.

United Nations Organization. (2015).2030 Agenda: Transforming Our World: The 2030 Agenda for Sustainable Development, New York. Retrieved on November 19, 2020, from https://nacoesunidas.org/pos2015/agenda2030/.

Pinheiro, J C, Rosa, M E N S, Silva, G G, Lima, J G C, \& Anjos Neto, D A A (2019). Importance of apical patency in the success of endodontic treatment. Revista Ciência e Odontologia , 3 (1), 15-19.

Ribeiro, E D P, Oliveira, J A, Zambolin, AP , Lauris, R P, \& Tomita , N E (2002). Integrated approach to the oral health of drug addicts in the process of recovery. Revista Pesquisa Odontológica Brasileira, 16(3), 239-245.

Sousa, C N, Souza, T C, \& Araújo, T L C (2015). Satisfaction evaluation s patients seen in clinical dental school in educational institution higher. Interfaces Magazine, 3(8), 01-05.

Valladares, L. (2007). The Ten Commandments of Participant Observation. Brazilian Journal of Social Sciences, 22(63), 153-155.

Vergara, S C (2006). Research methods in administration (2nd ed). São Paulo: Atlas.

Vieira, M P C N, Cruz, J H A, Medeiros, R S, Oliveira, A A, Gomes, M A S, Costa, C H M et al. (2021). Importance and influence of dental aesthetics related to the individual's biological and social health. Archives of Health Investigation , 10(5), 717-724. 